\title{
Rancang Bangun Sistem Informasi Penjualan Online Berbasis Webmobile
}

\author{
Arditya Himawan ${ }^{1}$, Toni Wijanarko Adi Putra ${ }^{2}$ dan Fitro Nur Hakim ${ }^{3}$ \\ 1,2,3 Jurusan Teknik Informatika STMIK ProVisi Semarang \\ Jl. Majapahit 304, Semarang \\ E-mail : arditya_himawan@yahoo.com¹,t.wijanarko@gmail.com²,masfitro@gmail.com³
}

\begin{tabular}{|c|c|}
\hline ARTICLE INFO & $A B S T R A C T$ \\
\hline $\begin{array}{l}\text { Article history: } \\
\text { Received } 30 \text { Mei } 2020 \\
\text { Received in revised form } 2 \text { Juni } 2020 \\
\text { Accepted } 10 \text { Juni } 2020 \\
\text { Available online } 12 \text { Juni } 2020\end{array}$ & $\begin{array}{l}\text { Gamerground is a computer shop engaged in the sale of } \\
\text { laptops, computers, spare parts, accessories supporting and } \\
\text { providing repair services. The marketing process is less } \\
\text { than optimal because it only sells by phone or social } \\
\text { media. There are some problems that occur between them } \\
\text { : 1. Stock management is not optimal because of frequent } \\
\text { discrepancies between stock records with the amount of } \\
\text { goods available so often consumers feel disappointed with } \\
\text { the services provided, } 2 \text {. The issue of uploaded ad duration } \\
\text { in uploaded social media will alternate from one product } \\
\text { content display to another in a relatively short period of } \\
\text { time, 3. The absence of management of consumer sales } \\
\text { transactions thus requiring recording of repeated } \\
\text { transactions, 4. The decline in sales turnover in recent } \\
\text { months, 5. The management of customer or consumer data } \\
\text { is less noticed. Based on these problems, this study aims to } \\
\text { design a web-based online sales information system } \\
\text { mobile on gamerground. This research uses the } \\
\text { development of SDLC waterfall model system which } \\
\text { consists of planning, analysis, design, implementation and } \\
\text { maintenance. Using PHP and MySQL Server } \\
\text { programming language as database. The results of } \\
\text { research in the form of Online Sales Information System } \\
\text { Web-Based Mobile that can facilitate consumers to view } \\
\text { products, make reservations for consumers and } \\
\text { management for the admin. This information system is } \\
\text { equipped with product management features, order data } \\
\text { management, customer data management, preparing order } \\
\text { reports and payment confirmation. So that this information } \\
\text { system can provide convenience both consumer and admin } \\
\text { on gamerground. }\end{array}$ \\
\hline
\end{tabular}

Keywords: Sales, Gamerground; Mobile Web

\begin{abstract}
Introduction
TEKNOLOGI internet kini sudah tidak asing lagi, kebutuhan masyarakat akan informasi yang cepat sangatlah mudah, dapat diakses oleh siapa saja, kapan saja dan di mana saja. Teknologi internet mempunyai efek yang sangat besar pada perdagangan atau bisnis. Dapat mengakses informasi barang dari mana saja baik dari harga, spesifikasi, dan melakukan transaksi pembelian. Hal ini sangat menghemat waktu dan biaya bagi calon pembeli, karena tidak perlu datang ke toko atau tempat transaksi sehingga dari tempat duduk saja mereka dapat mengambil keputusan dengan cepat.

Gamerground merupakan sebuah toko komputer yang bergerak dibidang penjualan laptop, komputer, spare part, accessories pendukungnya dan menyediakan pelayanan jasa perbaikan. Proses pemasaran yang kurang optimal karena hanya melakukan penjualan melalui telepon ataupun sosial media. terdapat beberapa masalah yang terjadi diantara nya (1) Manajemen stok belum optimal karena sering terjadi ketidaksesuaian antara catatan stok dengan jumlah barang yang tersedia sehingga sering kali konsumen merasa kecewa
\end{abstract}

Received Mei 23, 2020; Revised Juni 29, 2020; Accepted Juli 12, 2020 
dengan pelayanan yang diberikan. (2) Masalah durasi tayang iklan di sosial media yang diunggah akan silih berganti dari satu tayangan konten produk ke konten produk yang lain dalam waktu yang relatif singkat. (3) Tidak adanya pengelolaan terhadap transaksi penjualan konsumen sehingga mengharuskan pencatatan transaksi yang berulang-ulang. (4) Terjadinya penurunan omset penjualan dalam beberapa bulan terakhir. (5) Manajemen data pelanggan atau konsumen kurang diperhatikan (5)

Melihat kondisi tersebut maka diperlukan langkah-langkah diantaranya (1) Melakukan manajemen stok yang berkala agar antara catatan stok dan jumlah barang sesuai. (2) Perlunya pembuatan dan pengelompokan pada produk-produk yang dijual sehingga konten produk yang sudah di unggah tidak hilang begitu saja setelah durasi waktu tertentu. (3) Perlunya manajemen katalog produk yang baik agar produk-produk yang ditawarkan kepada calon pembeli bersifat persisten atau tahan lama. Dengan manajemen produk yang baik maka permasalahan terkait dengan penambahan dan pembaharuan produk dapat teratasi. (4) Perlunya Manajemen transaksi untuk mencatat setiap transaksi yang terjadi sehingga akan memudahkan penelusuran terhadap histori transaksi dari konsumen serta (5) Melakukan manajemen data pelanggan atau konsumen akan memudahkan pemilik usaha menjalin hubungan dengan konsumenya. Untuk melakukan penawaran atau promosi produk baru, produk diskon dan cuci gudang maka pemilik usaha akan dengan mudah menginformasikan kepada para konsumenya (5)

Berdasarkan uraian latar belakang tersebut, perlu adanya sebuah sistem informasi penjualan online berbasis web mobile yang dapat memberikan pelayanan yang lebih cepat kepada konsumen serta dapat memudahkan admin dalam melakukan pengelolaan produk serta transaksi penjualan di gamerground. Maka dilakukan penelitian dengan judul "Rancang Bangun Sistem Infomasi Penjualan Online Berbasis Web Mobile (Studi Kasus Gamerground Semarang).

\section{METODE PENELITIAN}

\section{Objek Penelitian}

Penelitian dilakukan di Gamerground Semarang yang berlokasi di Jalan Wonodri Krajan III No.677, Kecamatan Semarang Selatan, Kelurahan Wonodri, Kota Semarang Kode Pos 50242. Penelitian ini menjadi pilihan penulis dikarenakan pada Gamerground Semarang memiliki kekurangan pada sistem penjualan yang masih menggunakan sistem penjualan secara manual menggunakan telepon dan sosial media sebagai komunikasi, sehingga tidak efektif dalam menyediakan informasi dan layanan penjualan kepada konsumen.

\section{Metode Pengumpulan Data}

Pada penelitian ini penulis menggunakan teknik pengumpulan data sebagai berikut :

\section{Observasi}

Dalam penelitian ini melakukan observasi yaitu mengamati / melihat keadaan secara langsung pada proses penjualan dan pencatatan penjualan yang telah berjalan pada gamerground serta mengumpulkan informasi dan data-data yang dibutuhkan dalam kegiatan penelitian tersebut.

2. Wawancara

Dalam penelitian ini melakukan wawancara kepada pemilik, karyawan, dan konsumen. Dalam hal ini penulis mengajukan beberapa pertanyaan kepada pengurus di gamerground. Pertanyaan yang diajukan yaitu apakah Gamerground membutuhkan sistem baru untuk mempermudah pemesanan sparepart komputer. Berdasarkan hasil wawancara terhadap 20 responden tersebut $25 \%$ sangat setuju, $60 \%$ setuju, $10 \%$ tidak setuju, dan sisanya 5\% sangat tidak setuju.

3. Studi Dokumentasi

Dalam penelitian ini mendokumentasikan beberapa penjualan yang dilakukan dan mencari kelemahan dan kekurangan dari sistem yang lama.

4. Studi Pustaka

Dalam penelitian ini melakukan studi pustaka sebagai salah satu usaha untuk mendapatkan teori-teori dan informasi yang relevan dengan masalah yang sedang diteliti. Penulis memperoleh informasi tersebut melalui karya ilmiah, jurnal-jurnal, buku-buku, laporan penelitian dan dokumen yang berkaitan dengan penjualan.

\section{Metode Pengembangan Sistem}

Metode pengembangan sistem yang digunakan dalam penelitian rancang bangun sistem informasi penjualan online berbasis web mobile menggunakan Software Development Life Cycle (SDLC) dengan tahapan-tahapan sebagai berikut:

\section{Tahap Perencanaan Sistem (System Planning)}

Mendefinisikan masalah

Rancang Bangun Sistem Informasi Penjualan Online Berbasis Webmobile 
Masalah yang umum terjadi pada penelitian di gamerground adalah sistem penjualan dan ketersediaan barang yang sering terjadi.

Tujuan dan Manfaat

Tujuan dan manfaat dari perancangan sistem informasi penjualan online berbasis web mobile yaitu karena banyak pengguna smartphone/perangkat mobile serta untuk mengatasi masalah dan memberikan solusi terhadap permasalahan yang ada pada sistem pelayanan di gamerground, khususnya pada sistem penjualan, serta dapat menghasilkan sebuah sistem yang dapat membantu proses pemesanan yang lebih efektif, sehingga memudahkan admin untuk mengelola gamerground dalam pencatatan laporan penjualan serta keuangan.

\section{Tahap Analisis Sistem (System Analysis)}

a. Analisis Data dan Informasi

Data-data yang dibutuhkan dalam penelitian sebagai berikut:

1) Data Jenis Produk dan Harga Produk di Gamerground

2) Data Konsumen yang berupa Identitas pelanggan, alamat email dan nomor telepon

3) Informasi Data Diri Perusahaan, seperti nama, alamat perusahaan dan nomor telepon

4) Informasi Transaksi pemesanan dan pembayaran oleh konsumen kepada pihak Gamerground

\section{b. Analisis Sistem Lama}

Menganalisis kelemahan sistem yang ada dengan menggunakan usecase dan activity diagram. Prosedur dalam pemesanan di gamerground yaitu konsumen melakukan telepon terlebih dahulu, kemudian menanyakan barang yang mereka cari, penjual akan menjelaskan detail barang dan ketersediaan barang. Setelah terjadi kesepakatan antara kedua belah pihak, penjual akan menyediakan barang dan menuliskan nota pembelian, kemudian konsumen datang ke toko untuk mengambil barang dan melakukan pembayaran terhadap barang tersebut. Berikut ini adalah gambaran sistem yang sedang berjalan. ditunjukkan pada gambar 3.1

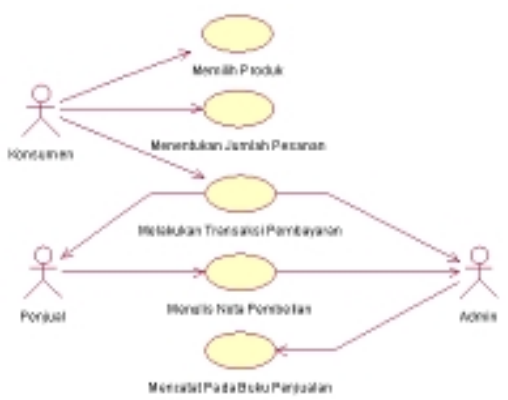

Gambar 3.1 Use Case Diagram Sistem Lama

Berikut ini alur sistem pemesanan pada Gamerground digambarkan secara rinci pada activity diagram. ditunjukkan pada gambar 3.2

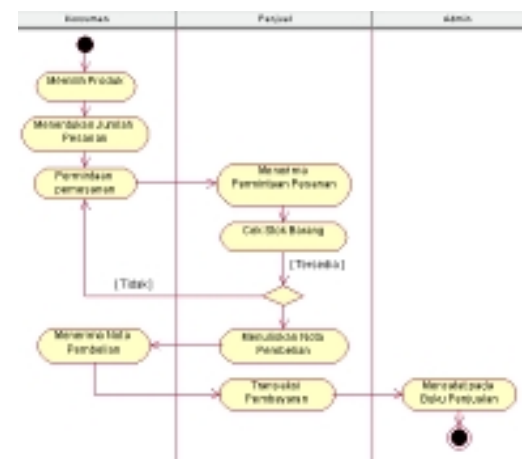

Gambar 3.2 Activity Diagram Sistem Lama

Activity Diagram Sistem Lama dapat dijelaskan sebagai berikut:

1) Konsumen memilih produk serta menentukan jumlah produk yang akan dipesan, kemudian melakukan permintaan pemesanan.

JURNAL ILMIAH ELEKTRONIKA DAN KOMPUTER Vol. 13, No. 1, Juli $2020: 44-59$ 
2) Penjual melakukan pengecekan stok barang yang dipesan

3) Konsumen menyelesaikan administrasi yang berupa pelunasan pembayaran dan menerima nota pembelian barang yang sudah termasuk dengan bukti pembayaran.

4) Admin akan mencatat nota penjualan pada buku penjualan.

\section{c. Kelemahan Sistem Lama}

Berdasarkan hasil analisis sistem lama, ditemukan beberapa masalah yang terjadi, diantaranya adalah:

1) Agar dapat memperoleh informasi produk konsumen harus menghubungi melalui telepon terlebih dahulu ataupun langsung mendatangi toko tersebut.

2) Transaksi pembayaran harus dilakukan di toko.

3) Terjadi Kesalahan yang pencatatan pemesanan, berupa kesalahan penulisan produk atau harga yang tak sesuai.

\section{d. Gambaran Sistem Baru}

Diharapkan sistem baru dapat membantu mengatasi permasalah yang terdapat pada sistem yang lama. Sistem Informasi Penjualan Online berbasis Web Mobile dirancang untuk mempermudah melakukan pemesanan, pencatatan data para konsumen, dan mempermudah penyampaian informasi produk kepada para konsumen.

\section{Tahap Perancangan Sistem (System Design)}

\section{a. Pemodelan Proses}

Penerapan pemodelan proses pada sistem informasi penjualan online berbasis web mobile secara garis besar yang melibatkan aktor dalam sistem. Activity diagram menjelaskan alur sistem dan semua aktifitas yang dilakukan aktor dan sistem.

1) Use Case Diagram

(1). Use Case Diagaram Konsumen

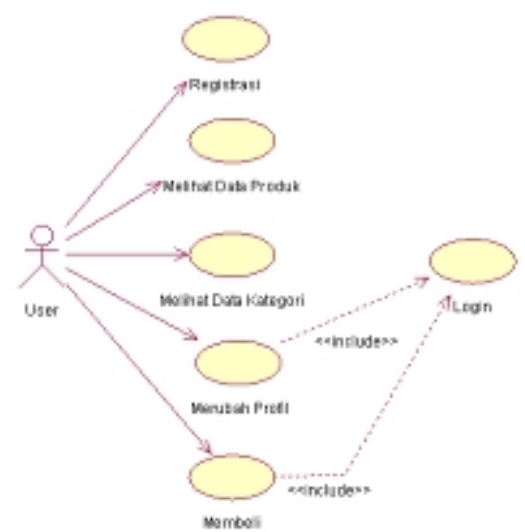

Gambar 3.3 Use Case Diagram Konsumen

2) Use Case Diagram Admin

(2). Use Case Diagram Mengelola Data Barang

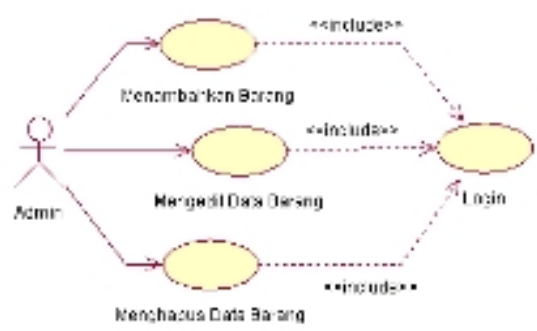

Gambar 3.4 Use Case Diagram Mengelola Data Barang

(3). Use Case Diagram Mengelola Data Kategori 


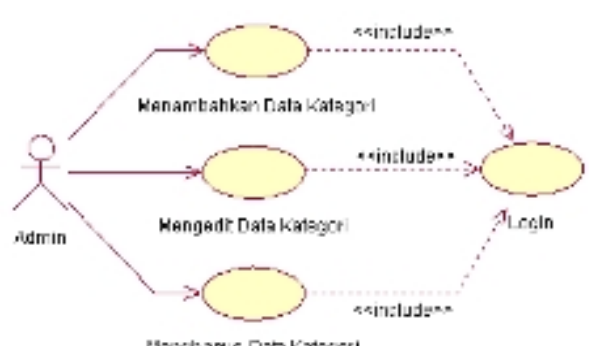

Gambar 3.5 Use Case Diagram Mengelola Data Kategori

(4). Use Case Diagram Mengelola Data Merk

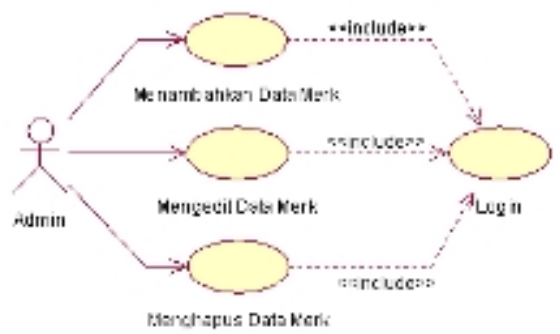

Gambar 3.6 Use Case Diagram Mengelola Data Merk

(5). Use Case Diagram Mengelola Data Kurir

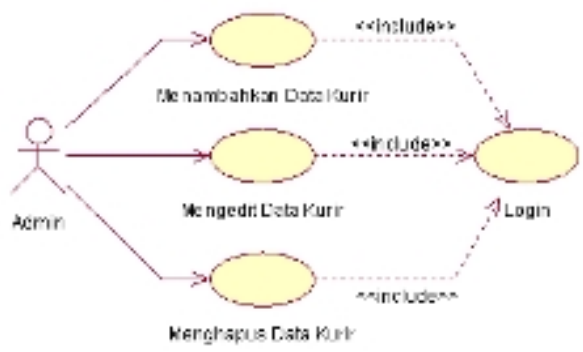

Gambar 3.7 Use Case Diagram Mengelola Data Kurir

(6). Use Case Diagram Mengelola Data Pelanggan

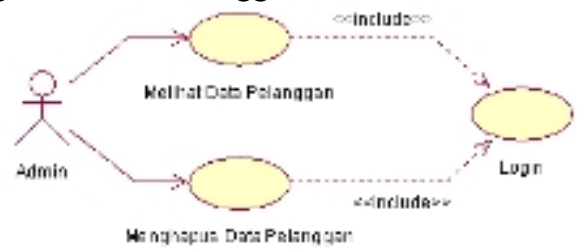

Gambar 3.8 Use Case Diagram Mengelola Data Pelanggan

(7). Use Case Diagram Mengelola Data Pesanan

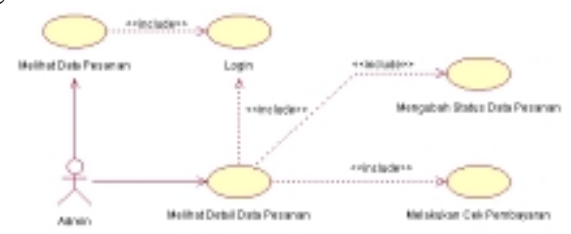

Gambar 3.9 Use Case Diagram Mengelola Data Pesanan

(8). Use Case Diagram Mengelola Laporan

JURNAL ILMIAH ELEKTRONIKA DAN KOMPUTER Vol. 13, No. 1, Juli $2020: 44$ - 59 


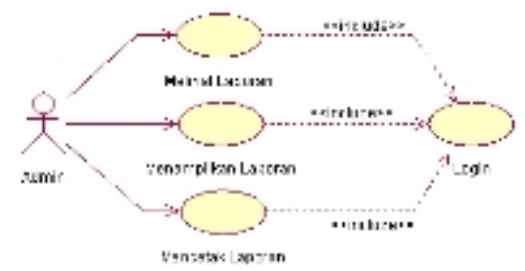

Gambar 3.10 Use Case Diagram Mengelola Data Barang

3) Activity Diagram

(1). Activity Diagram Registrasi User

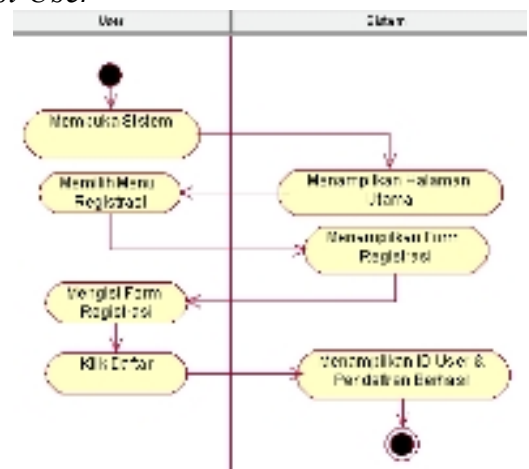

Gambar 3.11 Activity Diagram Registrasi User

(2). Activity Diagram Login

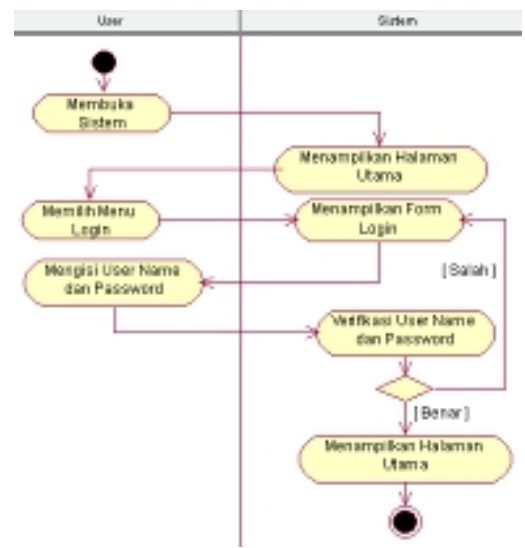

Gambar 3.12 Activity Diagram Login

(3). Activity Diagram Merubah Profil

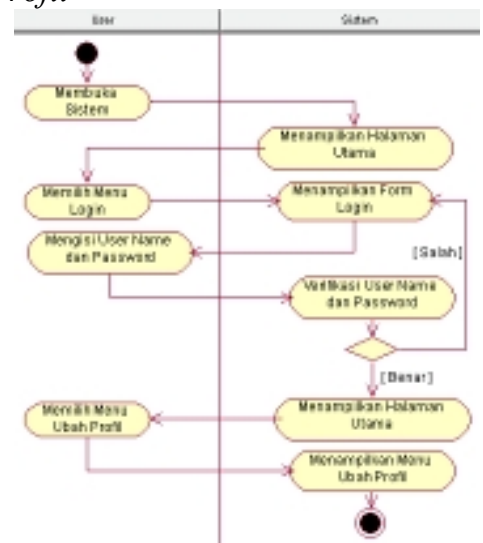

Gambar 3.13 Activity Diagram Merubah Profil 
(4). Activity Diagram Pembelian

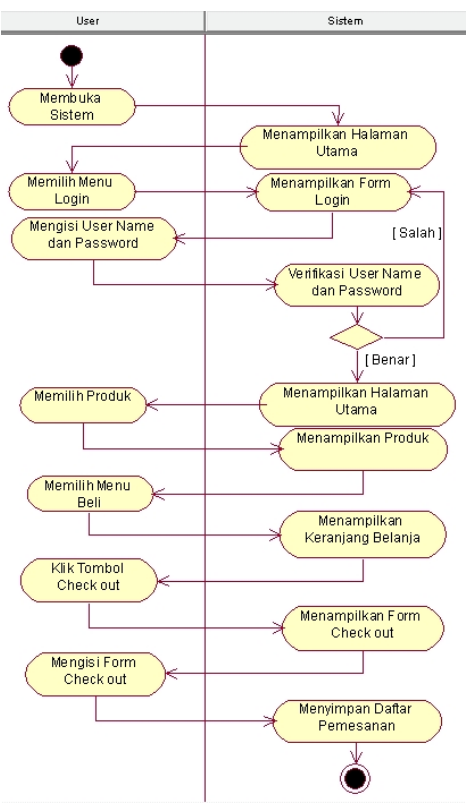

Gambar 3.14 Activity Diagram Pembelian

(5). Activity Diagram Lihat Produk dan Kategori

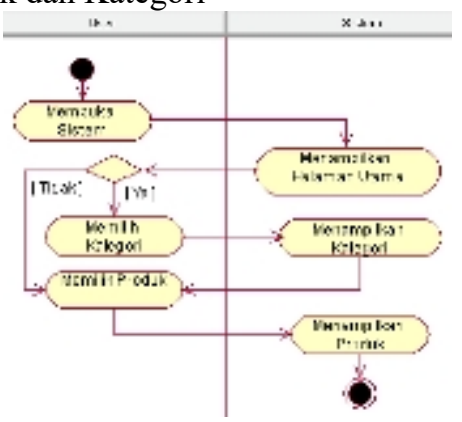

Gambar 3.15 Activity Diagram Lihat Produk dan Kategori

\section{b. Perancangan Pemodelan Data}

Menggambarkan relasi table dengan menggunakan ERD (Entity Relationship Diagram ).

Entity Relationship Diagram (ERD) Pembuatan Entity Relationship Diagram berkaitan antara data satu dengan yang lainnya.

c. Membuat desain antarmuka (Interface) sistem informasi penjualan online berbasis web mobile.

1) Desain Halaman Utama

Halaman Utama adalah halaman awal dari website yang menampilkan menu home, kategori, search, login, daftar serta produknya. Seperti ditunjukkan pada gambar 3.19

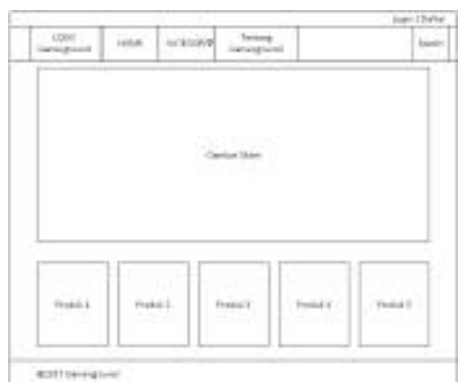

Gambar 3.19 Desain Halaman Utama

JURNAL ILMIAH ELEKTRONIKA DAN KOMPUTER Vol. 13, No. 1, Juli 2020 : 44 - 59 
51

JURNAL ILMIAH ELEKTRONIKA DAN KOMPUTERp-ISSN: $1907-0012$ e-ISSN : 2714-5417.

2) Desain Halaman Daftar (registrasi) dan Login

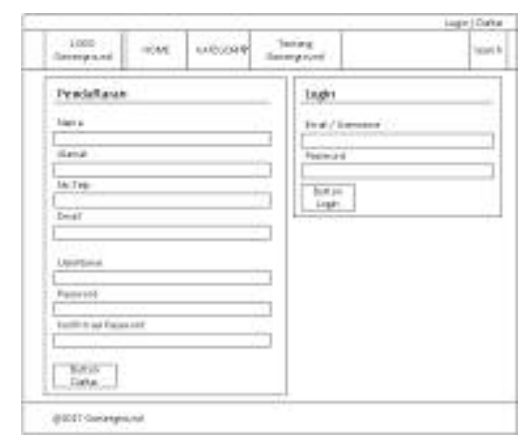

Gambar 3.20 Desain Halaman Daftar dan Login

3) Desain Halaman Produk

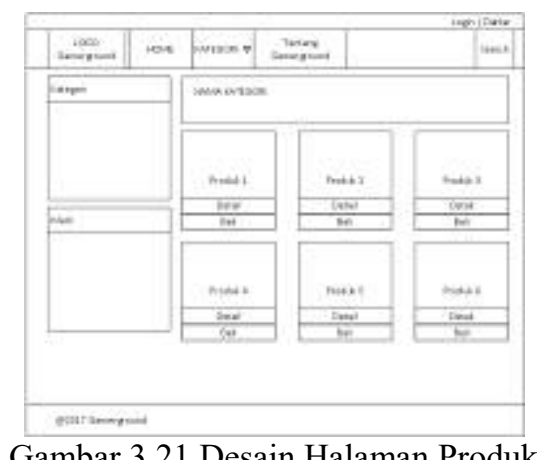

4) Desain Halaman Keranjang Belanja

Halaman Keranjang Belanja adalah halaman yang menampilkan barang yang akan dibeli sebelum melakukan proses selanjutnya. Seperti ditunjukkan pada gambar 3.22

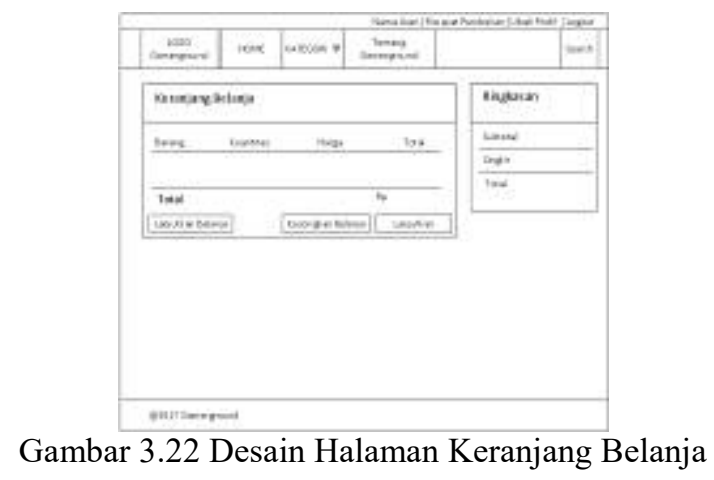

5) Desain Halaman Pembelian

Halaman Pembelian adalah halaman yang digunakan untuk melakukan proses. Seperti ditunjukkan pada gambar 3.23 


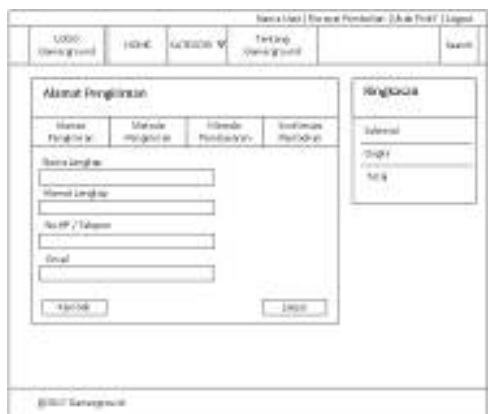

Gambar 3.23 Halaman Pembelian

6) Desain Halaman Riwayat Pembelian

Halaman Riwayat Pembelian adalah halaman dimana konsumen dapat melihat riwayat pembelian. Seperti ditunjukkan pada gambar 3.24

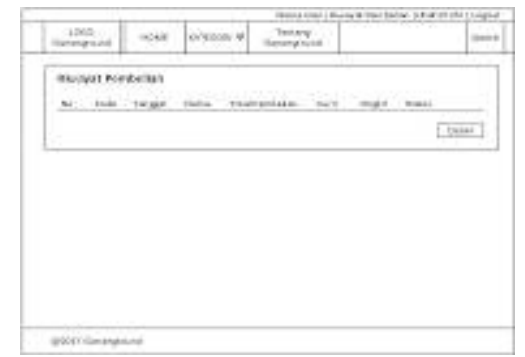

Gambar 3.24 Halaman Riwayat Pembelian

7) Desain Halaman Admin

Halaman Admin berisi data-data pengelola barang, pesanan, pelanggan serta laporan. Seperti ditunjukkan pada gambar 3.25

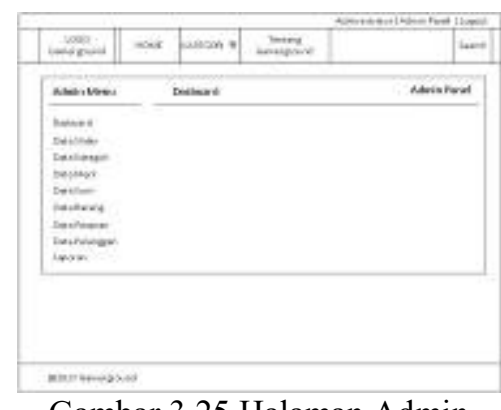

Gambar 3.25 Halaman Admin

\section{4,Tahap Penerapan Sistem (System Implementation)}

a. Hardware yang digunakan

Hardware yang dibutuhkan yaitu komputer dengan spesifikasi processor setara Intel Dual Core 2.4 Ghz, RAM DDR3 2 GB, Harddisk 500GB.

b. Software yang digunakan

Perancangan program membutuhkan software PHP dan MySQL sebagai database.

\section{Tahap Penggunaan dan Perawatan Sistem (System Maintenance)}

Tahap penggunaan merupakan tahap akhir yaitu menggunakan sistem berdasarkan fungsi dan tugasnya masing-masing untuk pengoperasian sistem secara rutin. Pada Perawatan sistem melakukan perbaikan pada saat pengoperasian terdapat masalah ( bugs). 
Pada tahapan implementasi membutuhkan hardware dan software dengan spesifikasi yang telah ditentukan untuk membuat sistem informasi penjualan online berbasis web mobile pada Gamerground, sebagai berikut :

1. Kebutuhan Hardware

Hardware yang digunakan dalam pembuatan sistem informasi penjualan online ini menggunakan spesifikasi komputer / laptop yang setara dengan processor intel Dual Core $2.4 \mathrm{Ghz}$, memory Ram DDR3 2GB, Harddisk 500GB, perangkat digunakan untuk melakukan pengujian sistem:

a. Smartphone iPhone 5S

b. Smartphone Polytron W6500

2. Kebutuhan Software

Software yang digunakan untuk membuat dan menjalankan rancang bangun sistem informasi penjualan online berbasis web mobile pada gamerground yaitu:

a. Web Server menggunakan Apache

b. Pemograman Web menggunakan PHP

c. Database menggunakan MySQL

Implementasi Perancangan Sistem

A. Tampilan antar muka (interface) konsumen (user)

a. Halaman Utama

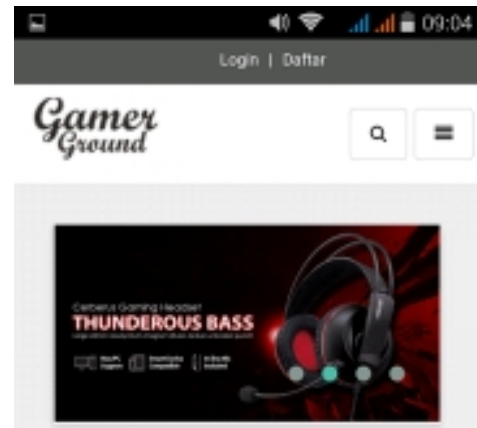

Gambar 4.12 Halaman Utama

b. Halaman Daftar

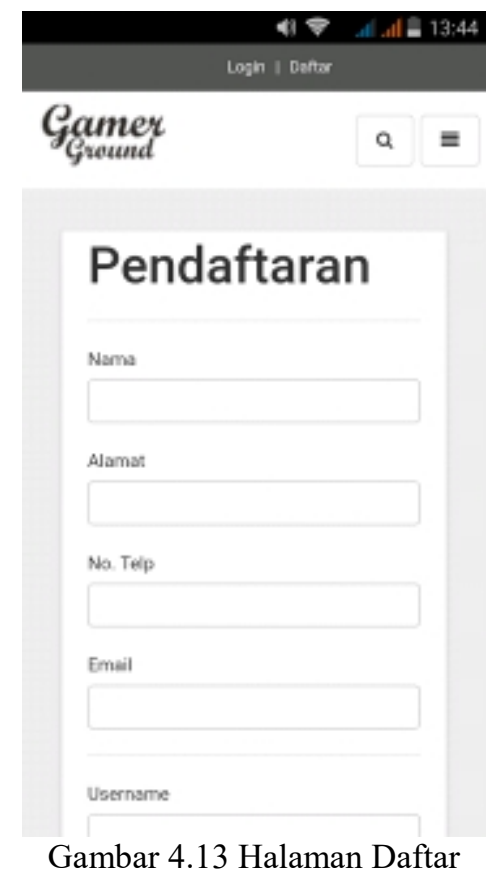


54

p-ISSN: 1907-0012 e-ISSN : 2714-5417

c. Halaman Login

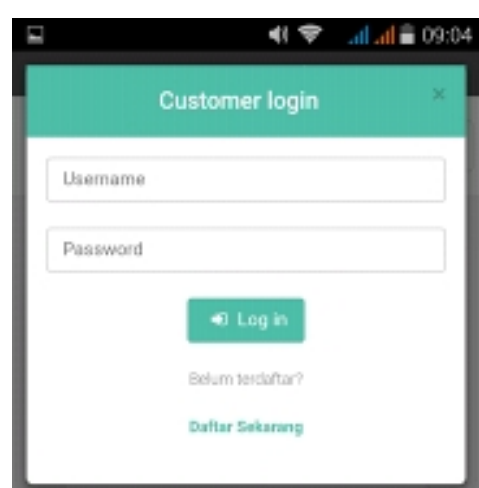

Gambar 4.14 Halaman Login

d. Halaman Produk

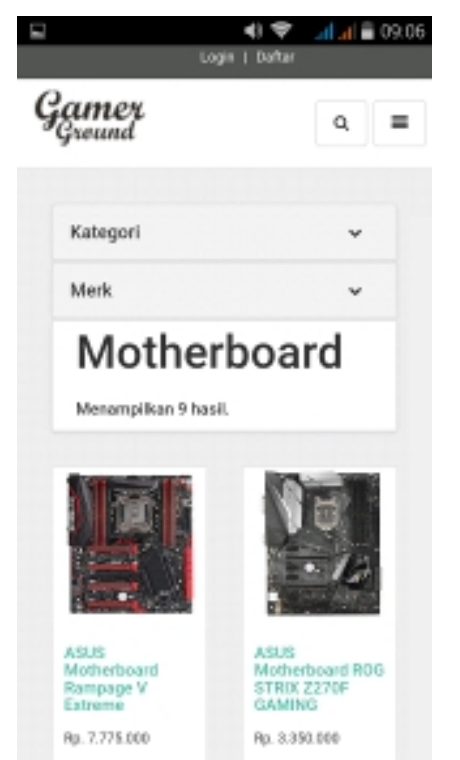

Gambar 4.15 Halaman Produk

e. Halaman Keranjang Belanja

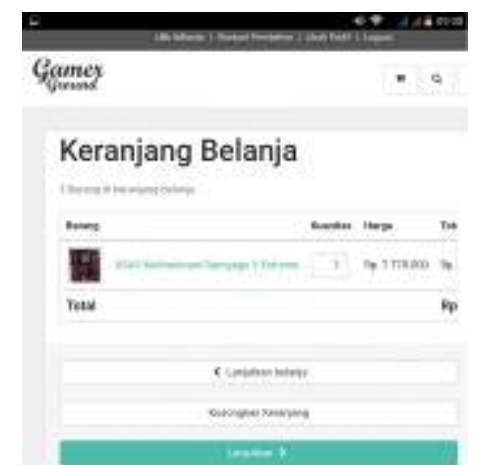

Gambar 4.16 Halaman Keranjang Belanja

f. Halaman Proses Pembelian dan Konfirmasi Pembelian

JURNAL ILMIAH ELEKTRONIKA DAN KOMPUTER Vol. 13, No. 1, Juli 2020 : 44 - 59 


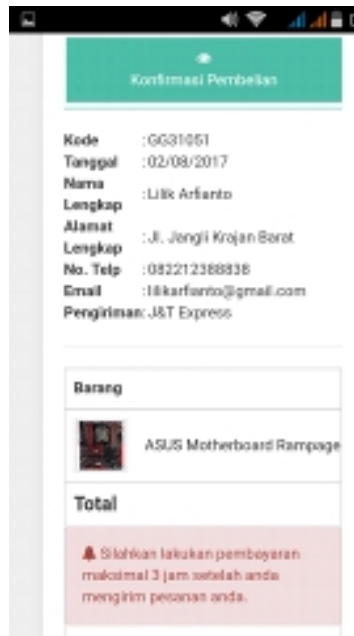

Gambar 4.17 Halaman Proses Pembelian dan Konfirmasi Pembelian

g. Halaman Konfirmasi Pembayaran

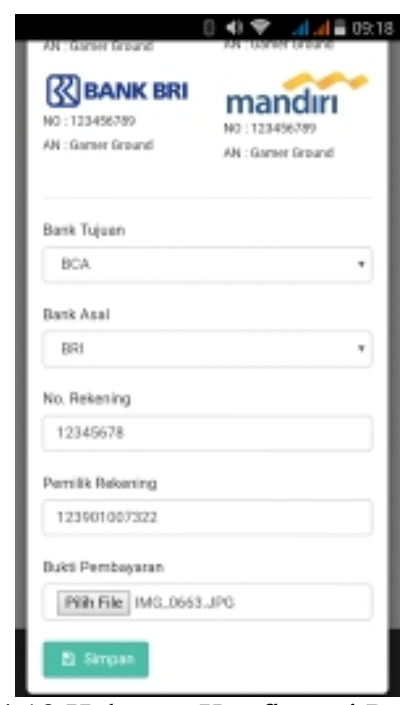

Gambar 4.18 Halaman Konfirmasi Pembayaran

B. Tampilan antar muka (interface) admin

a. Halaman Login

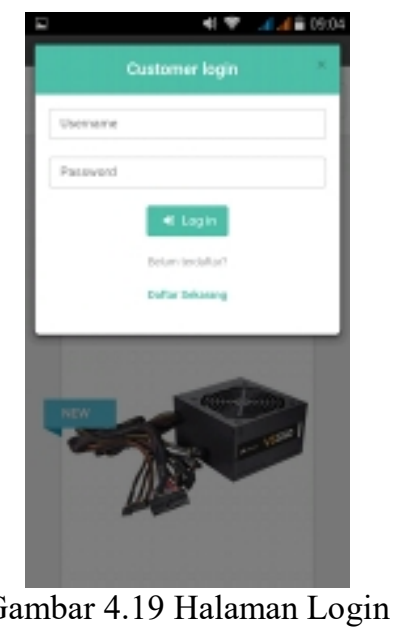

Rancang Bangun Sistem Informasi Penjualan Online Berbasis Webmobile 
b. Halaman Panel Admin

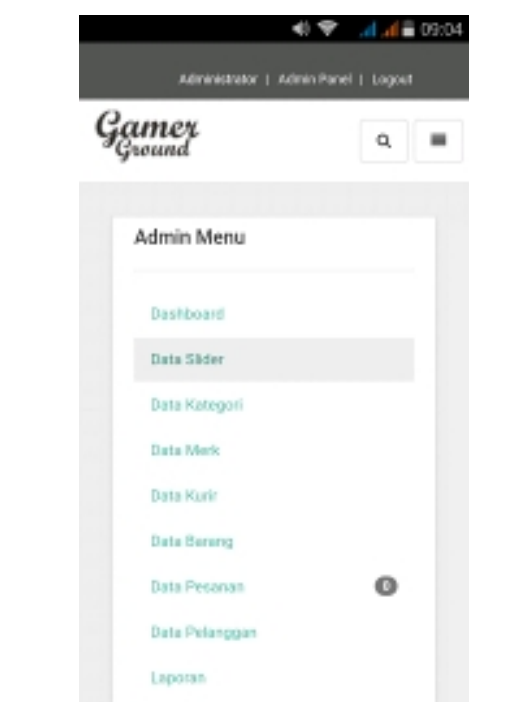

Gambar 4.20 Halaman Panel Admin

c. Halaman Data Barang

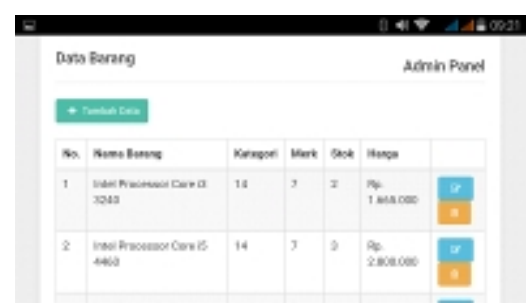

Gambar 4.21 Halaman Data Barang

d. Halaman Data Pesanan

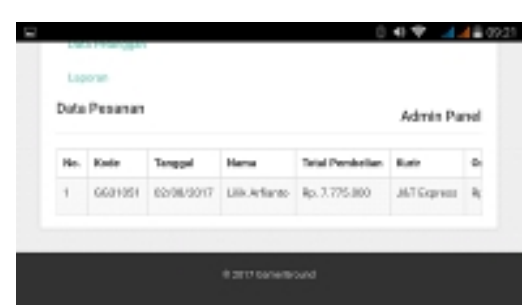

Gambar 4.22 Halaman Data Pesanan

e. Halaman Data Pelanggan

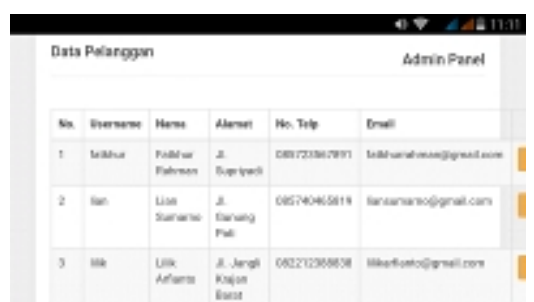

Gambar 4.23 Halaman Data Pelanggan

f. Halaman Laporan

JURNAL ILMIAH ELEKTRONIKA DAN KOMPUTER Vol. 13, No. 1, Juli 2020: 44 - 59 


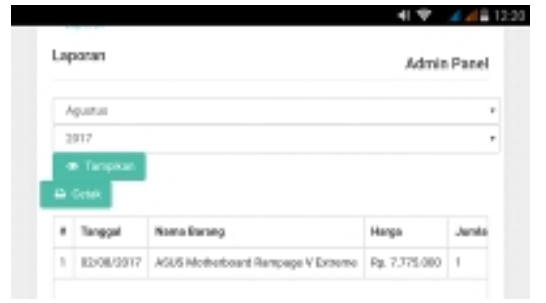

Gambar 4.24 Halaman Laporan

\subsection{Pengujian Sistem}

Adapun Pengujian sistem dengan teknik Blacbox yang akan diujikan terhadap sistem informasi penjualan online berbasis web mobile pada gamerground.

\subsection{Metode dan Pengujian}

Metode Pengujian sistem system informasi penjualan online berbasis web mobile ini menggunakan metode blackbox. Daftar use case, metode pengujian serta kriteria evaluasi hasil pengujian. Daftar usecase yang akan diuji yaitu, Admin dan Konsumen, seperti ditunjukkan pada table 4.2

\begin{tabular}{|c|c|c|l|}
\hline \multicolumn{4}{|c|}{ Tabel 4.2 Daftar use case } \\
\hline $\begin{array}{c}\text { Id Kasus } \\
\text { Uji }\end{array}$ & Use Case & $\begin{array}{c}\text { Metode } \\
\text { Pengujian }\end{array}$ & $\begin{array}{c}\text { Kriteria } \\
\text { Evaluasi Hasil } \\
\text { Pengujian }\end{array}$ \\
\hline UC-1 & Admin & Black Box & Pengelolaan data \\
\hline UC-2 & Konsumen & Black Box & $\begin{array}{l}\text { Melihat } \\
\text { Informasi dan } \\
\text { melakukan } \\
\text { pesanan }\end{array}$ \\
\hline
\end{tabular}

Pengujian ini dilakukan dengan memasukkan inputan tertentu serta melihat hasil dari inputan tersebut. Pengujian ini dilakukan untuk mengetahui hasil kinerja serta fungi dari perangkat lunak. Dari Hasil pengujian terakhir yang dilakukan dapat diperoleh hasil pengujian, dari hasil skenario pengujian pada setiap pilihan yang ada pada rancang bangun sistem informasi penjualan online berbasis web mobile ( Studi Kasus Gamerground Semarang ) yaitu menu Halaman Utama, Registrasi user, login user, Akses Halaman Ubah Profil, Melihat Data Produk, Melihat Data Kategori, Melakukan Pembelian dan menu dalam Admin seperti : Login, Halaman Panel Admin, Halaman Data Barang, Halaman Data Kategori, Halaman Data Merk, Halaman Data Kurir, Halaman Data Pelanggan, Halaman Data Pesanan, Halaman Laporan. Maka diperoleh hasil pengujian tersebut telah berhasil sesuai dengan yang diharapkan.

\subsection{Pembahasan}

Berdasarkan simulasi sistem informasi penjualan online berbasis web mobile pada gamerground. Berikutnya dilakukan pembahasan sistem, hasil, dan penilaian adalah sebagai berikut :

1. Rancang Bangun Sistem Informasi Penjualan Online berbasis web mobile yang telah dihasilkan dapat mempermudah konsumen dalam melakukan pembelian secara online, memudahkan konsumen dalam melihat produk-produk yang dijual, serta dapat memudahkan konsumen dalam melakukan konfirmasi pembayaran secara langsung melalui web.

Pada sistem yang lama masih menggunakan telepon dan sosial media dalam melakukan pemesanan produk. Sehingga terjadi beberapa masalah saat masih menggunakan sistem yang lama, yaitu: (1) ketidaksesuaian antara catatan stok dan jumlah barang yang tersedia, sehingga konsumen merasa kecewa terhadap pelayanan yang diberikan, (2) Masalah durasi tayang iklan di sosial media yang diunggah akan silih berganti dari satu tayangan konten produk ke konten produk yang lain dalam waktu yang relatif singkat, (3) Tidak adanya pengelolaan transaksi / nota penjualan konsumen sehingga terjadi pencatatan yang berulang-ulang, (4) Terjadi penurunan omset, dan (5) Manajemen data pelanggan yang kurang diperhatikan.

Dengan adanya sistem informasi penjualan online ini dapat mengatasi yang terjadi pada sistem yang lama, diantaranya : (1) Tidak terjadi nya ketidaksesuaian catatan stok dan jumlah barang, karena pada informasi produk telah ditampilkan stok barang yang tersedia. (2) Durasi tayang iklan yang relatif singkat yang sebelumnya ada pada sosial media, sekarang tidak ada lagi dengan cara membuat katalog produk, sehingga calon pembeli tidak kehilangan momentum melihat produk yang terpasang akibat durasi tayang yang relatif singkat. Seperti ditunjukkan pada gambar 4.15 (Halaman Produk) (3)

Rancang Bangun Sistem Informasi Penjualan Online Berbasis Webmobile 
Manajemen transaksi / nota penjualan yang lebih memudahkan admin dalam melakukan pengelolaan data transaksi / nota penjualan serta laporan penjualan di gamerground (4) Menajemen data pelanggan relatif lebih cepat dan terpusat, karena untuk melakukan pembelian produk harus mendaftar terlebih dahulu, sehingga data pelanggan yang telah terdaftar dapat dimanfaatkan untuk melakukan promosi terhadap pelanggan yang telah terdaftar melalui data pelanggan yang telah terdaftar. Sedangkan (5) Diharapkan dengan adanya sistem ini dapat meningkatkan omset penjualan pada gamerground.

2. Dari Hasil penelitian yang telah dilakukan tersebut, dihasilkan suatu sistem informasi yang dapat memudahkan admin dalam melakukan manajemen, diantaranya :

a. Manajemen data produk lebih mudah dilakukan, karena terdapat menu data barang yang memudahkan admin dalam memanajemen produk, diantaranya seperti (1) menambahkan produk (2) menghapus produk (3) mengedit produk. sehingga admin dapat mudah melakukan kontrol terhadap produk yang akan dijual. Seperti ditunjukkan pada gambar 4.21 (Halaman Data Produk).

b. Manajemen Data Pesanan lebih mudah dilakukan, karena saat konsumen melakukan pembelian produk, admin akan mengetahui bahwa terdapat pesanan baru yang masuk kedalam data pesanan, pada data pesanan tersebut admin dapat melakukan kontrol, dengan melakukan perubahan status pada pesanan yang telah dilakukan konsumen, melalui data pesanan tersebut admin dapat melakukan cek pada konfirmasi pembayaran yang telah dilakukan oleh konsumen. sehingga tidak terjadi lagi pencatatan yang berulang-ulang. Seperti ditunjukkan pada gambar 4.22 (Halaman Data Pesanan).

c. Manajemen data pelanggan lebih mudah dan relatif lebih cepat, karena data terpusat dan akan muncul pada data pesanan setelah konsumen melakukan pendaftaran, sehingga dapat memudahkan admin dalam melakukan promosi produk dengan menggunakan informasi data pelanggan yang telah tersedia, diantaranya dengan nomor telepon dan email. Seperti ditunjukkan pada gambar 4.23 (Halaman Data Pelanggan).

d. Manajemen Laporan lebih mudah dilakukan melalui menu laporan yang telah tersedia, sehingga admin dapat mengetahui laporan transaksi penjualan berdasarkan bulan ataupun tahun. Seperti ditunjukkan pada gambar 4.24 (Halaman Laporan).

Dengan adanya sistem informasi penjualan online berbasis web mobile ini manajemen data produk, data pesanan, data pelanggan, serta laporan lebih mempermudah admin dalam melakukan pengelolaan data pada gamerground semarang.

3. Dari Hasil penelitian yang telah dilakukan ini, dihasilkan suatu solusi untuk mengatasi masalah-masalah yang terjadi :

a. Penulisan nota yang berganda tidak terjadi lagi dikarenakan dari pembelian produk tersebut, akan masuk secara langsung ke dalam data pesanan sehingga penulisan nota yang berganda/berulangulang tidak terjadi. Seperti ditunjukkan pada gambar 4.22 Halaman Data Pesanan.

b. Kesalahan Kontrol Stok Barang dapat teratasi dengan adanya Data Barang yang ada pada sistem, sehingga saat akan melakukan input produk yang baru pada data barang tersebut terdapat kolom stok yang digunakan untuk menginput stok barang yang ada, yang dapat memudahkan kontrol stok barang.

c. Kesalahan Perhitungan Laporan Keuangan juga dapat diatasi dengan adanya halaman laporan dimana semua transaksi akan masuk pada halaman laporan, sehingga dapat memudahkan dalam melakukan perhitungan laporan keuangan pada gamerground. Seperti ditunjukkan pada Gambar 4.24 Halaman Laporan.

Dengan Adanya sistem informasi ini dapat mengatasi masalah penulisan nota yang berganda, kesalahan dalam melakukan kontrol stok barang, serta perhitungan laporan keuangan pada gamerground.

4. Dari Hasil Penelitian yang telah dilakukan juga didapatkan suatu proses yang lebih baik pada sistem yang baru diantaranya :

a. Konsumen dapat langsung melihat informasi produk yang mereka cari secara detail dibanding kan pada sebelumnya yang melalui telepon, karena saat melalui telepon konsumen hanya dapat mengetahui dari penjual yang menjelaskan barang saja, tidak secara detail, sehingga dengan di sistem ini konsumen lebih cepat mendapatkan informasi produk yang mereka cari,

b. Konsumen pun dapat melakukan pembelian lebih cepat pada sistem ini karena saat konsumen melakukan pembelian produk, secara langsung akan masuk ke dalam data pesanan yang terdapat pada sistem dan dapat diketahui dengan cepat oleh admin gamerground yang akan melakukan konfirmasi dari pembelian yang telah dilakukan oleh konsumen, Seperti ditunjukkan pada gambar 4.22 (Halaman Data Pesanan).

JURNAL ILMIAH ELEKTRONIKA DAN KOMPUTER Vol. 13, No. 1, Juli $2020: 44-59$ 


\section{DAFTAR PUSTAKA}

[1] Amsyah, Zulkifli. 2010. Manajemen Sistem Informasi. Jakarta.

[2] Hizair, MA. 2013. Kamus Lengkap Bahasa Indonesia. Jakarta: TAMER.

[3] Kadir, Abdul. 2014. Pengenalan Sistem Informasi Edisi Revisi. Yogyakarta: Andi.

[4] Kroski, Ellyssa. 2008. On the Move with the Mobile Web: Libraries and Mobile Technologies - What Is the Mobile Web?. Library Technology Reports, [online] : www.techsource.ala.org, [27 Agustus 2017].

[5] Nugraha, Rikky Wisnu dan Budiman, Asep Syarip. 2014. Perangkat Lunak Pemesanan Pembuatan Software CV Valiodological \& Feeling Berbasis Web. Bandung : Jurnal LPKIA, Vol 1, No. 1

[6] Nugroho, Adi. 2010. Rekayasa Perangkat Lunak Menggunakan UML \& Java. Yogyakarta: Andi Offset.

[7] Prabowo, Pudjo Widodo. 2011. Menggunakan UML. Informatika. Bandung.

[8] Pressman, R.. 2010. Software Engineering A Practitioner's Approach th Edition. Unites States : Mc

[9] Ristono, Agus. 2009. Manajemen Persediaan. Yogyakarta : Graha Ilmu

[10] Sugiono, Arief., Yanuar Nanok Soenarno dan Synthia Madya Kusumawati, 2010. Akuntansi \& Pelaporan keuangan: untuk bisnis sekala kecil dan menengah, Jakarta: Grasindo.

[11] Sulistiyowati, Leny. 2010. Panduan Praktis Memahami Analisis Laporan Keuangan, Jakarta: PT Elex Media Komputindo.

[12] Supriyanto, Aji. 2007. Pengantar teknologi informasi. Jakarta : Salemba Infotek.

[13] Sutabri, Tata. 2012. Konsep Dasar Informasi. Yogyakarta: Andi Offset.

[14] Sutarman. 2012. Pengantar Tekhnologi Informasi, Jakarta: Bumi Aksara

[15] Williams, B.K. and Sawyer, S.C. 2011. "Using Information Technology: A Practical Introduction to Computers \& Communications. (9th edition)". New York: McGraw-Hill.

[16] Wong, Jony. 2010. Internet Marketing for Beginners, Elex Media Komputindo, Jakarta.

[17] Yakub. 2012. Pengantar Sistem Informasi, Yogyakarta: Graha Ilmu. 